\title{
PRZEDSŁOWIAŃSKA WARSTWA NAZEWNICZA PÓŁNOCNEGO MAZOWSZA - POPRAWKI I UZUPEŁNIENIA (DORZECZE NARWI)
}

W wydanej przed kilkunastu laty propozycji syntezy najstarszej warstwy nazewniczej ziem polskich (autor 2001) podjąłem próbę wyodrębnienia grupy nazw geograficznych, których moment powstania należałoby umieszczać w dobie tradycyjnie określanej jako starożytna. Z oczywistych względów konieczne było zastosowanie wnioskowania pośredniego o charakterze postgnozy, odwołującego się do cech formalnych nazw oraz niekiedy dodatkowej argumentacji pozajęzykowej (charakter i tzw. ranga nazywanych obiektów). Było i jest oczywiste, że nie ma żadnej pewnej i bezpiecznej metody pozwalającej bezbłędnie wyodrębniać nazwy o metryce starożytnej; ani brak motywacji leksykalnej na gruncie języków historycznych (w tym wypadku słowiańskich, zwłaszcza polszczyzny), ani istnienie motywacji leksykalnej na gruncie języków niesłowiańskich, ani obecność nazw podobnych na terenach nie objętych historycznym osadnictwem słowiańskim nie mogą tu mieć charakteru rozstrzygającego. $Z$ tych powodów tak zdefiniowaną warstwę najstarszą (czy przedsłowiańską) należy rozumieć w sensie Popperowskim - jako zbiór nazw, których nie udało się dotąd wyjaśnić na gruncie języków historycznych, zbiór z jednej strony uszczuplany przez nowe ustalenia slawistyczne, z drugiej wciąż uzupełniany nowymi niejasnymi toponimami odkrywanymi w sukcesywnie udostępnianych źródłach historycznych.

Podstawowym mankamentem pracy było niewystarczające wykorzystanie materiału mikrotoponimicznego, wynikające z nieprzeprowadzenia systematycznej kwerendy olbrzymiego, wciąż tylko częściowo upublicznionego zbioru nazw terenowych zebranych na przełomie lat 50. i 60. (projekt znany jako UN - Urzędowe nazwy miejscowości i obiektów fizjograficznych). W wielu wypadkach nie zdawałem sobie w pełni sprawy ze skali powtarzalności tej czy innej nazwy. Tymczasem kryterium powtarzalności i łączliwości z produktywnymi morfemami nazwotwórczymi ma podstawowe znaczenie dla oceny historii danego typu nazwy i wiarygodności rekonstrukcji implikowanego przez nią motywującego apelatywu. ${ }^{1}$ Ten aspekt opracowania właściwie nie został wytknięty przez krytykę, w onomastyce polskiej wciąż brak bowiem należytego zrozu-

* Instytut Filologii Słowiańskiej Uniwersytetu Jagiellońskiego, ul. Władysława Reymonta 4, 30-059 Kraków, Polska; zbigniew.babik@uj.edu.pl

1 Rozsądną wartością brzegową jest przyjęcie, że nazwa powtarzająca się czterokrotnie lub częściej (zwłaszcza na obszarze wielkości dzielnicy średniowiecznej Polski, np. Mazowsza) ma metrykę młodsza, średniowieczną lub nawet późniejszą, bez względu na to, czy motywujący apelatyw zachował się w polszczyźnie. 
mienia walorów poznawczych mikrotoponimii, wynikających w pierwszym rzędzie z masowości tego materiału.

Jednym z ważniejszych rezultatów pracy było uwypuklenie odrębności północnego Mazowsza, wyrażającej się tak dużym, większym niż na innych terenach zagęszczeniem nazw zaliczonych do tej warstwy, jak i pewnymi cechami formalnymi (większy udział femininów na $*_{-i-}$, brak formantu -awa w hydronimii). Toponimia ta nie ukazała jednak swego własnego oblicza - niezależnie od obecności tu nielicznych elementów uznanych za germańskie lub bałtyckie, większość nazw została uznana za niejasne etymologicznie i etnojęzykowo, zdefiniowane jedynie negatywnie względem możliwości „nazwodawczych” historycznej toponimii słowiańskiej.

Od dłuższego czasu, realizując inny projekt badawczy, zajmuję się systematyzacją polskich materiałów (mikro)toponimicznych. W dotychczas przebadanej ich części ujawniła się pewna liczba nowych nazw uderzających swą strukturą i zarazem nieprzejrzystością motywacyjną, bądź też nazw tworzących gniazda z nazwami znanymi juz wcześniej i rzucających światło na ich historię. Ze szczególną wyrazistością sytuacja ta wystąiła właśnie na północnym Mazowszu, skłaniając mnie do podjęcia próby usystematyzowania tych przykładów w sposób podobny, jak uczyniłem to w książce. Wyodrębniam zatem te toponimy, które z największym stopniem prawdopodobieństwa mogą być traktowane jako przynależnie do tak zdefiniowanej warstwy najstarszej - przedsłowiańskiej; w grupie tej umieściłem przede wszystkim nazwy sprawiające wrażenie dawnych złożeń, gdzie ze względu na obecność dwóch morfemów leksykalnych ryzyko uznania nazwy rodzimej za obcą jest szczególnie małe. Prezentuję tutaj głównie wstępne etapy badania, polegające na opisaniu dokumentacji tych toponimów oraz próbie odtworzenia ich ewolucji na gruncie polskim i rekonstrukcji prapostaci w momencie przejmowania do słowiańskiego, kwestie związane z właściwą interpretacją etymologiczną i ,etnojęzykową" pozostawiając zasadniczo na uboczu. Ze względu na narzucone ograniczenia objętościowe ograniczam się wyłącznie do dorzecza Narwi (wraz z Wkrą) i tylko do nazw, których do najstarszej warstwy nie zaliczyłem w roku $2001 ; 2$ niestety, miejsca zabrakło również na wiele innych szczegółów. O nazwach Mława i Turośl pisałem w innych miejscach (autor 2004; 2008: 36-37), do uwag tam przedstawionych nie mógłbym obecnie dodać wiele nowego.

Chachtuza - nazwa rzeki w okolicach Ostrołęki, znana z pojedynczego zapisu ([1565] LuMazXVI II 43: < na rzece Chachluzie >), wedle dotychczasowej wiedzy nie zachowana we współczesnej warstwie mikrotoponimicznej. Identyfikacja nie jest jasna, nazwę podano bez kontekstu (nie wiemy nawet, czy leżała w prawej, czy w lewej

2 Przypomnijmy, że zaliczono tu (autor 2001: 92 i passim) nazwy Drwęcz, Dybła, Ełk, Jakać, Kubra, Kumielsko, Lutobrok, Łaś, Łomża, Łydynia, Narew, Omulew, Orzyc, Oskobłok, Pelta, Pisa, Pryskat, Rumoka, Szkwa, Trłoga, Wegra, Wincenta, Wissa, Wizna, Wkra, Wszerzecz. Z tej grupy wyłączyć należy Kubrę (formalistycznie, ze względu na istnienie nawiązań apelatywnych w leksyce słowiańskiej, o czym niebawem w innym miejscu) i Łaś (zapewne jest to nazwa rodowa o pierwotnym brzmieniu Łaszy $\rightarrow$ Łasze, później syngularyzowana, zob. teraz NMPol VI 284, s.v. Łaś; zmiana $s z>s$ tłumaczy się mazowieckim siakaniem). Większość pozostałych nazw wymaga dalszej, nakierowanej głównie na drugorzędne szczegóły dyskusji. 
części dorzecza Narwi); o rzece wiadomo tylko tyle, że zdolna była napędzać koło młyńskie. Postać Chachluza (<Chachtuża?) należy zestawić3 z górnośląskim hydronimem zapisanym w r. 1308 (w kopii z roku 1696) jako <Cocolug $>$ (SNGŚ II 14). ${ }^{4}$ Autorzy tego słownika (zapewne sam H. Borek) odczytali nazwę jako Chochoług i objaśnili jako zrost od Chochot i tug (Chochottug > Chochotug), co przekonywać nie może. Domański (1989: 175) rekonstruował Kocioług (!) nie zauważając, że w okolicach Orzesza nadal funkcjonuje pokrewna nazwa (stawu i osady), ustandaryzowana w PRNG jako Hochołóg (!). ${ }^{5}$ Mimo widocznych różnic zdaje się nie ulegać wątpliwości, że chodzi o wtórne warianty formalne tego samego charakterystycznego złożenia, mogącego stawać się nazwą wodną (casus podobny do stosunku Oskobłok: Osobłoga, opisanego w Najstarszej warstwie). Mimo podobieństwa drugiego członu do słowiańskich apelatywów topograficznych $(* l u g z, * l u z ̌ a)$ całość sprawia mocno podejrzane wrażenie (przegląd słowiańskiej leksyki apelatywnej na *xax-, *xox- w ĖSSJa VIII 10-11, 53-56). Praformę obu nazw trudno jednak zrekonstruować w sposób autorytatywny. Wahania -g- : -z- (-dz-) w wygłosie tematu, spowodowane nie do końca jasnymi przeszeregowaniami fleksyjnymi na podstawie reinterpretacji miejscownika, są w nazewnictwie polskim znane (por. Bańkowski 1982: 85).

Duświeta - standaryzacja nazwy gwarowej (UN CXXXIII 48) brzmiącej Duśfeta (UNMasz CXXXIII 48). Według źródeł jest to nazwa pola we wsi Nowy Susk (pow. Ostrołęka). Standaryzację trzeba ocenić jako udaną, w gwarach mazowieckich zachodzi bowiem regularna dyspalatalizacja wargowej w podobnych grupach spółgłoskowych (zob. poszczególne opisy fonologiczne u Basary 1984). Nieoczekiwane z fonetycznego punktu widzenia jest zakończenie -eta (bez refleksu żadnego z przegłosów), stan taki może być jednak wtórny - w wypadku dawnego $* \check{e}>* a$ wynikając ze zmiany $a>e$ po palatalnych, obserwowanej na Mazowszu, w przypadku $*_{e}>*_{o}$ ze zniesienia alternacji w kierunku uogólnienia tematu miejscownika (*Duświota: loc. Duświecie, skąd nowe Duświeta itd. w nowszej epoce). Prapostacią byłoby zatem (po)prasłowiańskie *Dusveta lub *Dusvěta.

Forma uderzająco przypomina polską transpozycję litewskiej nazwy wodnej brzmiąca Duświaty (jezioro i dobra w okolicach Troków, litew. Trakai, pod Wilnem). $\mathrm{Na}$ nazwę taką udało się natrafić $\mathrm{w}$ kilku opracowaniach polskich dostępnych w Internecie, nie natrafiono natomiast na wariant litewski tej nazwy, nie odnotowany u Vanagasa 1970 (*Dūsvetos? *Dūsvetai?). Polskie nazwy jeziorne z obszaru Litwy i Białorusi zakończone na -aty kontynuują zwykle substratowe -intai, -entai, niekiedy

3 Pewne podobieństwo wykazuje także Chochołódka -i, nazwa pola we wsi Paczółtowice w pow. Chrzanów (UN IV 24). Wahania $-d-(-t-):-g-,-\dot{z}-$ nie wyjaśnimy jednak bezproblemowo.

4 Według hydronimicznej bazy danych IJP PAN jest to mały strumień (ok. $4 \mathrm{~km}$ ) w basenie Rudy we wsi Palowice. Por. też HO nr 38: Chochoług a. Kocoług. Notowano także nazwę niezlokalizowanego ściśle młyna $<$ Chocholug $>$ w zapisie z r. 1505 (SNGŚ 1.c.). Podana przez Mycielskiego postać nazwy osady Chacholug ma chyba hiperpoprawne $a$ (wobec śląskiej zmiany $a ̊ o$ ).

5 W polskim systemie ortograficznym postacie graficzne Chochoług i Hochołóg opiewają na to samo brzmienie [xoxounuk]. Postać z $H$ - pojawia się na mapie niemieckiej (,setce”, arkusz Sohrau) z 1884 r., osobliwa pisownia bazuje zatem chyba na podciągnięciu pod niem. hoch. 
jednak także -etos itp. (litew. Dusetos : pol. Dusiaty). Mielibyśmy tu zatem bardzo charakterystyczną zbieżność $\mathrm{z}$ toponimią litewską, i to raczej w formie implikującej późne zapożyczenie do słowiańskiego.

Jaboraziec - standaryzacja nieznanej (w mławskim „maszynopisie profesorskim” UNMasz CXXXI nazwy tej brak) nazwy gwarowej łąk we wsi Mdzewo w pow. Mława (UN CXXXI 21: dop. Jaboraźca). Nazwa nieznana z innych źródeł (brak jej m.in. w PRNG, co uniemożliwia ściślejszą lokalizację), izolowana i ciemna, sprawiająca wrażenie rodzimego derywatu (zapewne deminutywnego) podstawowego złożenia *Jaboraz lub *Jaboraź (w ostateczności *Jaboraż, z możliwym siakaniem $\dot{z}>\dot{z}$ ). Oba prawdopodobne człony są niejasne, kuszące byłoby zestawienia drugiego z nazwami Sochoraż (mikrotoponim) i Chodorażek < Chodorasko (zob. NMPol II 57: nazwa na -sko, niejasne), położonymi na zachodniej peryferii Mazowsza i w Ziemi Dobrzyńskiej. Należałoby jednak przyjąć nieregularną denazalizację lub niedoskonałe przekazanie postaci nazwy.

Kupęs - funkcjonująca współcześnie nazwa lasu we wsi Pery (dop. Kupęsia; pow. Zambrów, z lokalizacją 81,2/94,5 w „maszynopisie profesorskim”), ściśle zlokalizowana na mapie (PRNG), jednak pozbawiona starszej dokumentacji (nie notuja jej Wolff i Rzetelska-Feleszko 1982). Nazwa izolowana i ciemna, bez nawiązań apelatywnych i antroponimicznych. Niewykluczone przekształcenie jakiejś odmiennej postaci (np. *Kupęść), przypuszczenie takie opiera się jednak wyłącznie na intuicji. Postać zaświadczona wskazywałaby najprędzej na prapostać * Kuposь (temat męski na *-i-). Postać sprawia raczej wrażenie złożenia (w znanych językach niesłowiańskich tej części Europy brak sufiksów, których wczesne formy mogłyby zostać zeslawizowane jako *-osb), ale struktura takiej formy nie jest jasna (gdzie należałoby postawić granice morfologiczne?).

Lutostań - nazwa lasu i osady (obecnie wsi, gm. i pow. Łomża), dotąd uważana za rodzimą i objaśniana $\mathrm{w}$ związku $\mathrm{z}$ etymologicznie prawdopodobną, choć nie zaświadczoną nazwą osobową * Lutostan (Zierhoffer 1957: 243; NMPol VI 246 s.v.). Jednakże charakterystyka gramatyczna (dop. Lutostani) wskazuje na femininum na spółgłoskę. Sugerowano (NMPol 1.c.), że maskulinum *Lutostań zostało wtórnie feminizowane, zmiana taka nie jest jednak potwierdzana przez niezależne przesłanki; przeciwnie, dwa zapisy średniowieczne sugerujące końcowe $-i(<$ de Luthostani $>$ [1436, kopia 1456] SHGMaz (MK 3, 193); <in Luthosthany> [1452, kopia 1457] ib. (ib. 4, 6)) stanowią zapewne staropolskie formy dopełniacza i miejscownika, potwierdzając tym samym dawność obecnej fleksji nazwy. ${ }^{6}$ Fleksja taka jest, jak wiadomo, sprzeczna z założeniem derywacji dzierżawczej formantem *-jb (oczekiwana byłaby forma $\uparrow$ Lutostania,

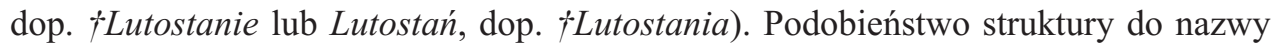
Rzechostań (p. niżej), o niejasnym pierwszym członie, skłania do poniechania prób interpretacji nazwy na gruncie pra- czy staropolskim.

6 Trzeci zapis, późniejszy o kilkadziesiąt lat $<$ Cothy alias Luthostany > [1480], [1493] (NMPol V 213, s.v. Koty (2)), zapewne oznacza już jotowaniem miękkość końcowego -ń (por. tamże $<$ de Cothy alias Luthosthan > [1473], <Cothy Luthostan> [1509], [1523]). 
Mańkań - tak należy standaryzować nazwę zaświadczaną zapisami średniowiecznymi jako dwa lub trzy gniazda hydronimiczne w dorzeczu Narwi. Według HW (208, odcinek 539) nazwę Mankan nosiły dwa niesąsiadujące ze sobą prawe dopływy Orzu; przed XVIII w. zaświadczono by też brzmienia Makania i Makana. Trzecia podobna lub identyczna nazwa miała zostać zaświadczona w średniowieczu dla prawego dopływu rzeki Penzy na wschód od Łomży. Udało się potwierdzić, że nazwa z dorzecza Orzu przetrwała co najmniej do połowy XX w. - w kwerendzie UN-owskiej zapisano ją jako Mańkoń (dop. Mańkonia) dla pola we wsi Wojsze (pow. Ostrołęka, niepublikowany „maszynopis profesorski” UNMasz CXXXIII 8; brak w PRNG). ${ }^{7}$ Samogłoska $o$ stanowi tu niewątpliwie refleks dawnego å, które w tej części Mazowsza zachowało się jako odrębna samogłoska (por. enklawę oznaczoną na mapie 52 u Dejny 1981), ewoluując następnie w kierunku $o .{ }^{8}$ Męskie końcówki należy chyba traktować jako innowację w świetle prawdopodobnej postaci żeńskiej na $-a .^{9}$

Liczba gniazd nazewniczych zawierających tę nazwę jest trudna do jednoznacznego określenia. Pewnym punktem oparcia jest jednoznacznie zidentyfikowany obiekt z Wojsz. Raczej wiarygodną informacją jest umiejscowienie równobrzmiącej nazwy w dorzeczu Penzy lub Dzierzbi (według bazy danych IJP PAN chodzi o zapis $<$ rivulo Mankan> [1414-25, kopia 1456] SHGMaz (MK 3, 65) ${ }^{10}$ ). Istnienie trzeciego gniazda może być kwestionowane. Postać <Mankan> została zapisana w roku 1428 (MKsM I nr 579); 10 włók (ok. 170 ha) ziemi położonej nad tą rzeką oraz Jakacią zostało sprzedanych Janowi i Piotrowi z Gostkowa przez Piotra z Milewa. Na tej postawie w bazie

$7 \quad$ Analiza zawartych w maszynopisie informacji lokalizacyjnych (której metodyki nie mogę tu z braku miejsca przedstawić) zdaje się wskazywać, że pole znajdowało się w południowozachodniej części Wojsz. Ciek noszący tę nazwę należy zatem identyfikować z kilkukilometrową strugą, dopływem Orzu uchodzącym na zachód od centrum wsi.

8 Nie wiemy, czy zapis ten odzwierciedla istotnie pomieszanie dawnego $a$ z $o$, czy może jedynie błędną percepcję samogłoski lub świadome uproszczenie zapisu.

W opisie fonologicznym gwary wsi Wysocze, położonej ok. $9 \mathrm{~km}$ na południe od Wojsz (pkt. 285 OLA), opartym na materiałach zebranych przez B. Falińską w latach 1970 i 1973 (a więc kilka(naście) lat po akcji UN-owskiej) odnotowano sporadyczne występowanie $o$ jako kontynuantu å przed nosowymi (Basara 1984: 84: przykłady boćọ < bociån, mọ < måm). W tymże opisie potwierdzono, że gwara Wysocza zachowała odpowiedniki literackich nosówek ę i $q$ jako $\dot{e}$ i $\dot{Q}$, w pozycji przed zwartymi rozkładane na sekwencje $e N, o N$ (ib. 82), przy czym przed tylnojęzykowymi powstaje fonetyczne $\eta$. Wynika stąd, że w takim systemie sekwencja zapisana jako -ań- nie może być sprowadzona do staropolskiej samogłoski nosowej.

9 Nie można do końca wykluczyć, że postać $<$ Makanya $>$, użyta po łacińskiej formie dopełniacza, sama stanowi dopełniacz nazwy - rodzaju męskiego (!). Zapis $\mathrm{z}<q>$ przemawiałby za fonologiczną nosówką, możliwe jednak, że litera $\langle q\rangle$ zastąpiła zawarte w protografie $*<a n\rangle$ dopiero podczas kopiowania zapisu w $1498 \mathrm{r}$.

10 Weryfikacja identyfikacji zapisów hydronimów mazowieckich pochodzących ze źródeł niepublikowanych jest trudna, bowiem wypisy dostępnie w bazie danych IJP PAN zwykle nie zawierają kontekstu. Ostatnio w Internecie udostępniono wprawdzie w wolnym dostępie zeskanowaną kartotekę SHGMaz, jednak jest ona usystematyzowana według miejscowości; odszukanie przekazów nazw wodnych wymagałoby uprzedniego ustalenia/odgadnięcia, pod którymi miejscowościami zostały one zaszeregowane. 
danych IJP PAN uznano obiekt za lewy dopływ Jakaci, przypisano mu również zapis $<$ fluvii Makanya > [1464, kopia (?) 1498] SHGMaz (MK 9, 218) o nieznanym kontekście. Tymczasem z treści notatki nie wynika jednoznacznie, że obszar ziemi, o którym była mowa, miał charakter zwarty; mogło chodzić o dwa kawałki terenu położone w dwu różnych miejscach. Uznanie w HW nazwy $<$ Mankan $>$ za przysługującą ostatniemu nazywanemu prawemu dopływowi Orzu jest chyba pomyłką. Ostateczny osąd należy zawiesić aż do zapoznania się z kontekstem zapisów z lat 1414 i 1464.

Formalnie biorąc, nazwa dopuszcza łączenie jej w gniazdo z udokumentowaną od średniowiecza nazwą lasu $\operatorname{Manc}(z)$, ponowioną następnie na kilka okolicznych osad. Również ta nazwa - czego nie notują dotychczasowe opracowania (Zierhoffer 1957: 244; Wolff, Rzetelska-Feleszko 1982: 100; NMPol VI 259, s.v. Łady-Mans) - w postaci bliskiej formie średniowiecznej przetrwała do XX w. jako nazwa lasu Moniec koło wsi Dąbek i Stylągi (UN CXXXIII 8; UNMasz CXXXIII 5: Dąbek i 8: Stylągi, forma Mońec; PRNG: Moniec). Brzmienie (Mānc > Moniec, ale także Mānc > Mans) stanowi zasadniczy argument przeciwko rekonstrukcji samogłoski nosowej; koresponduje z nim grafia licznych zapisów średniowiecznych, w których litera $<n>$ nigdy nie jest opuszczana (co często zdarza się przy notowaniu fonologicznych nosówek). Nazwa ta brzmiała zatem Mancz lub Manc, co wyklucza przyjmowaną dotąd za Zierhofferem (l.c.) etymologię wychodzącą od rodzimej nazwy osobowej *Męk $\sim{ }^{*} M a k$ (> ojkonim dzierżawczy Męcz). Powiązanie nazw Manc(z) i Mańkań byłoby możliwe przy założeniu przedsłowiańskiej praformy *Mānik-, która w obu nazwach była adaptowana rozmaicie; w nazwie lasu z palatalizacją pierwszą ( $>$ Mancz, przy założeniu fleksji miękkiej na $*_{-} i o-$ lub fleksji na $*_{-i-}$ ) lub trzecią, indukowaną przez $*_{-i-}>*_{-b-}(>$ Manc), natomiast w nazwie rzecznej z formantem $*_{-a n b}<*-a \bar{n} i$ - bez palatalizacji (*Mānikāni-). Jednakże powtarzanie się nazwy Mańkań w dorzeczu Penzy lub Dzierzbi (a może i w prawym dorzeczu Orzu) pozbawia tę koncepcję atrakcyjności. Manc daje się objaśnić na gruncie rodzimym $\left({ }^{*}\right.$ Manьcb, z północnopolskim rozwojem jerów przez bezdźwięcznymi, por. mazowieckie Stawc > Stawiec itp.), podstawa man- może nawiązywać do rodziny czasowniki *maniti (por. pol. manowce 'bezdroża').

Nuna - nazwa wsi ukazująca się w XIX w. (dziś gm. Nasielsk, pow. Nowy Dwór Maz.), bez kontekstu onimicznego (zob. NMPol VII 546: Nuna [1877], [1886], [1921], [1981], niejasna). Polszczyzna zna wprawdzie apelatyw nuna oznaczający (często z odcieniem lekceważenia) 'zakonnicę', zapożyczony z języków zachodnioeuropejskich (bezpośrednie źródło nie jest pewne), nie wydaje się on jednak wiarygodnym etymonem nazwy. Nazwisko *Nuna nie jest znane (zob. SSNO i Snazw). Można podejrzewać, że nazwa miejscowa ponowiona została z nieuchwytnej obecnie nazwy terenowej (nie notowanej też u Wolffa i Rzetelskiej-Feleszko 1982), której prapostać późnoprasłowiańską należałoby ustalać jako *Nuna lub może *Nona. *Nuna może wywodzić się m.in. z formy *Naun-, co przypomina zaświadczoną w staropruskich katechizmach postać przymiotnika 'nowy' (nauns itd.), którego relacja do indoeuropejskiego *neuo- $\sim$ *nouo- nie jest wszakże jasna (często przyjmuje się późne przekształcenie starszego *nauina-, zob. Mažiulis 1988-1997/III: 171). W toponimii pruskiej występują także inne nazwy o podobnym brzmieniu (Przybytek 1993: 195; NMPol VII 546, s.v.v. Nunkajmy i Nuny). 
Oględa - nazwę tę nosiła w XIV-XVI w. rzeka (ok. 20 km długości) w dorzeczu Orzyca (dzisiejsza Morawka) ${ }^{11}$ oraz położona nad nią wieś. K. Zierhoffer (1957: 283) uznał ojkonim za równy nazwie osobowej (nie wzmiankując w ogóle istnienia równobrzmiącej nazwy rzecznej), co przyjąłem za dobrą monetę (2001), nie włączając nazwy do najstarszej warstwy. Okazuje się, jednak, że dokumentacja tego gniazda nazewniczego wkracza w XIV w., zaś antroponimy * Ogląd, * Oględa itp., choć etymologicznie prawdopodobne, nie są w ogóle zaświadczone w polskich zbiorach. W szczególności, nie występują one w średniowiecznych źródłach mazowieckich (por. SSNO). Należy zatem przyjąć, że pierwotna w gnieździe jest nazwa rzeczna, zawierająca zapewne ten sam nieproduktywny (obcy?) sufiks co omówiona niżej Walęda $(*$ Oględa). Jeżeli odrzucić analizę *O-ględ-, nawiązania apelatywne odszukać możemy zarówno staropruskim ( $<$ aglo $>$ E $47<*$ agla lub *aglu 'deszcz', wyraz niezupełnie jasny, nieznany innym językom bałtyckim ${ }^{12}$ ), a także w gockich agls 'nieprzyjemny' i aglus 'ciężki, trudny', znanych też w innych językach germańskich (zob. o nich Lehmann 1986: 10-11 s.v.v.). Występowanie wokalizmu $a$ w nazwie Walęda przemawia jednak przeciwko przejęciu nazwy bezpośrednio z gockiego, a pośrednio w ogóle przeciwko gockiej genezie sufiksu *-ęd-.

Rudokiew - według UN CXL 10 jest to nazwa łąk we wsi Wola Błędowska (pow. Przasnysz, nazwa nie notowana w PRNG). Postać (dop. Rudokwi) uderza archaiczną fleksją na *-y -ъve przy nieprzejrzystości części końcowej. Z punktu widzenia etymologii nazwa nawiązuje zapewne do nazwy koloru (stopnie apofoniczne *Raud- i *Rūd- wydają się bardziej prawdopodobne niż *Rud-). Pierwiastek ten, jak wiadomo, jest reprezentowany w słowiańskim we wszystkich tych stopniach apofonicznych, ale struktura słowotwórcza skłania do zaliczenia toponimu do warstwy przedsłowiańskiej. Zapewne była to pierwotna nazwa niewielkiego cieku, ponowiona następnie na pobliskie łąki. Prapostać późnoprasłowiańska *Rudoky - bve. Godny podkreślenia jest brak korelacji rdzennego $R V d$ - z sufiksalnym - $a k$ - w hydronimii litewskiej (por. Vanagas 1970: 348, 349-350), podobne -ok-<-ak- odnajdujemy natomiast w północnomazowieckim toponimie Rumoka < Romoka (autor 2001: 243-244; 2008: 29).

$\boldsymbol{R} \boldsymbol{u} \dot{\boldsymbol{z}}$ i Ró $\dot{\boldsymbol{z}}$ - dzisiejsze postacie dwu nazw rzecznych, lewego i prawego dopływu Narwi. Ujścia tych rzek leżą w dość znacznej odległości od siebie (ok. $40 \mathrm{~km}$ w linii prostej), jednak obie nazwy wywodzą się zapewne od tego samego etymonu i kontynuują tę samą prapostać. Ustalenie jej napotyka na poważne trudności. Róż udokumentowany jest kilkoma zapisami średniowiecznymi ${ }^{13}$ od prawdopodobnej nazwy dopływu lub górnego biegu utworzono nazwę Rudziecko > Ruzieck (NMPol XII 85-86 s.v.).

11 Por. dostępną w hydronimicznej bazie danych IJP PAN dokumentację: Oglanda [1381] SHGMaz (AG 842); fluvii Oglanda [1414-25, kopia 1456] ib. (MK 3, 119); Oklanda [1427] MKsM I nr 513 i 515; Oglanda [1452, kopia 1457] SHGMaz (MK 4, 10); Oględa (postać standaryzowana) [XVI w.] AtMaz 248. Brak autentycznych przekazów hydronimu po XVI w. Dokumentacja istniejącego do dziś ojkonimu rozpoczyna się w roku 1414 (NMPol VIII 46, s.v. Oględa).

12 Por. Toporov 1975-1990/I: 58-59. Znaczenie 'deszcz' rozwinęło się prawdopodobnie z 'ciemność; ciemna, deszczowa chmura' itp.

13 Ruz [1450, kopia 1456] SHGMaz (MK 4, 100); Rusz [1474] ib. (ib. 6, 61); Ruz [1583] ib. (Roż. 3, 222); Róż a. Ruż (!) [1965] HW 207 (odc. 538). 
Nieoczekiwane $d z ́$ próbuje się objaśniać paraetymologią (1.c.). Obficiej udokumentowano nazwę rzeki Ruż. ${ }^{14}$ Obok postaci standardowych zanotowano jednak również femininum Ruza (Ruża), zaś w nowszych przekazach - femininum Ruź (dop. Ruzi, UNMasz CXXXIII 42: rzeka we wsi Gostery; ib. 44: krzaki we wsi Tyszki-Nadbory i Podruźe - $a$, pole tamże) i wtórne względem niej Ruś (dop. Rusi, ib., rzeka we wsi Mieczki-Poziemaki - ale tamże pole i łąka Podruźe -a; Ruś Rusi, rzeka we wsi MilewoŁosie ib. 43; rzeka Ruś Rusi w zambrowskim UNMasz). Występowanie derywatów na -ec przemawia za pierwotnie męskim rodzajem obu nazw. Wydaje się zatem, że paletę znanych form najłatwiej objaśnić przy założeniu praformy Ruż (> zmazurzone $R u z$ od połowy XV w.). Postać Ruziec (zamiast †Ruzec) wyjaśnić można bądź siakaniem, bądź nową derywacja/dostosowaniem do formy zmazurzonej $R u z$. Również genezę formy Ruza można wyjaśnić zmianą paradygmatu przez innowacyjną fonetycznie postać Ruz (wspólny miejscownik Ruzie). Natomiast postać Ruź -i powstałaby skutkiem zmiany paradygmatu przez formę mianownika zawierającą refleks siakania.

Nikły skład fonetyczny postaci $R u z$ utrudnia rozpoznanie pierwotnej struktury i pochodzenia nazwy, nie znajduje ona jednak nawiązań apelatywnych na gruncie słowiańskim. Powtarzanie się tej samej struktury w nazwach dwóch dużych cieków przemawia przeciwko rozważanej przeze mnie (autor 2001: 546-547, z inną rekonstrukcją prapostaci *Rudjb $>* R u d z$ ) interpretacji dzierżawczej (z sufiksem *-jb).

14 Por. zapisy: a fluvio Russ [1378 lub 1379, kopia] NKDMaz III 235 (nr 219); Ruziec [1393] HMil 434; Rusz [1414-25, kopia 1456] SHGMaz (MK 3, 10); Ruszecz [1414-25, kopia 1456] ib. (ib. 3, 38); Rus [1417] HMil 487; Ruszecz [1426] MKsM I nr 231; Russz [1438, kopia 1456] SHGMaz (MK 3, 216); fluvii Ruza (gen.?) [1473] ib. (ib. 6, 26v-27); Rvssz [1476] ib. (ib. 6, 77); Rusch [1493] ib. (ib. 18, 80-80v); Rusch [1495] ib. (ib. 18, 80-80v); rzeka Russa, na rzece Ruszie, na rzece Rusz [1565] LuMazXVI II 40, 90, 100; Rusz [1617-20] LuMazXVII I 105; Ruź [1781] ZMak 17; Rus Fl. [1808] MpTex VIII; Ruż a. Ruź; gb. <Rużec> HW 200 (odc. 520).

W niepublikowanym łomżyńskim tomiku UN podano: Ruź -zia, struga we wsi Rybaki (UN CLXI 19); Ruż -a, las i łąki we wsi Jastrząbka Młoda (ib. 45); Ruź -zia, rzeka we wsi Szabły Młode (ib. 49). Zapewne należy tutaj również nazwa Rus - a (UNMasz CXXXIII 41: łąki we wsi Andrzejki-Tyszki). Nadto w pow. ostrołęckim notowano nazwę Podruźe -a (UN CXXXIII 43: pole i łąka we wsi Piotrowo).

Identyfikacja najstarszego zapisu może budzić wątpliwości, jako że wydawcy NKDMaz III (235, przyp. 7) skłonni byli identyfikować go z Łomżyczką. Jak się okazuje, rzekomo niezidentyfikowana nazwa $B(z)$ dziqżek jest oznaczana współcześnie na mapach Geoportalu (Orto), ale ujęto ją także w HW 201 (odc. 520); jest to prawy dopływ dolnego Ruża, płynący ze wschodu na zachód i uchodzący pod Miastkowem. Staje się jasne, że wydawcy nie wniknęli w istotę treści opisu, a w dokumencie NKDMaz nr 219, ustalającym granice wsi Szczepankowo i dóbr Wszerzecz, opisano wszystkie granice tych dóbr: północną stanowił Bdziążek, południową Szczmielnik, który należy identyfikować zapewne z dzisiejszą Trzaską (por. Geoportal Orto), zachodnią Ruż, zaś wschodnią płynąca pod Boguszycami Łomżyczka. Wszystkie te cztery naturalne granice znajdują się w podobnej odległości od Szczepankowa i Wszerzeczy, położonych w centrum wyznaczanego przez nie obszaru. Por. tekst: ,habuerunt et habent granicies incipiendo a torrente vulgariter dicto Bdzanzek ex una parte in longum et latum usque ad torrentem Sczmyknyk ex altera parte et incipiendo a fluvio Russ usque ad torrentem currentem ante villam Boguschicze". Nie opisano tu granic w sensie dzisiejszym, a raczej obszar dóbr, zamykając go w pasach opisanych z północy na południe i z zachodu na wschód. 
Prawdopodobnie odrębny problem przedstawia geneza nazwy miasta Różana, położonego kilkanaście km w dół Narwi od ujścia Różu. W zapisach tej nazwy występuje konsekwentnie $<_{O}>$ (por. NMPol XI 135 s.v. Różan), co pozwalałoby wiązać go z Różem tylko przy założeniu wczesnej, przypadającej przed połową XV w. i nieregularnej zmiany $o \mathrm{w} u$ w hydronimie.

Rzechostań - tak najprędzej należałoby standaryzować mikrotoponim zarejestrowany jako Žexostań (dop. Žexostańi) przez eksploratora UN we wsi Filochy (pow. Ostrołęka, UNMasz CXXXIII 42: pole). Wprawdzie redaktor zeszytu ${ }^{15}$ (UN CXXXIII 42) zaproponował postać Grzechostan - $u$, jednak ani wprowadzenie dodatkowej spółgłoski do nagłosu, ani zmiana fleksji z miękkiej żeńskiej na twardą męską nie mają merytorycznego uzasadnienia, thumacząc się zapewne chęcią „uracjonalnienia” nazwy poprzez przekształcenie jej z niemotywowanej w niby-motywowaną. Nic nie wskazuje, by redaktor dysponował starszą dokumentacją mikrotoponimu. Brak dokumentacji nazwy sprzed XX w. uniemożliwia jednoznaczną rekonstrukcję jakości nagłosowej spółgłoski; w miejscowej gwarze pierwotne $r z$ i $\dot{z}$ powinny rozwijać się odmiennie (odpowiednio, $\mathrm{w} \check{z} \mathrm{i} z$ ), ale $\mathrm{w}$ tym drugim wypadku niewykluczona jest hiperkorekcja przeprowadzona już na poziomie informatora lub nawet gwary jako takiej (*Zexostań $\rightarrow$ Žexostań).

Nazwa, niezależnie od wyboru jednej z tych opcji (możliwe prapostacie * Rexostanb, *Rěxostanb, *Žexostanb, nawet *Žěxostanb $>*$ Žaxostanb) jest niejasna w pierwszym członie (brak odpowiednich apelatywów polskich i słowiańskich ${ }^{16}$ ), a człon drugi znajduje nawiązanie w postaci Lutostań (p. wyżej).

Siryga - nazwa bagna, zapisana podczas kwerendy UN-owskiej we wsi Pomocnia (pow. Pułtusk; niewydany UN CXLI 22; gwar. Siryga $-i$ UNMasz CXLI 35). Nazwa nierozkładalna nazwotwórczo, bez całościowych nawiązań apelatywnych i antroponimicznych. Prapostać raczej *Siryga niż *Širyga.

Smosarz - nazwa wsi ustalona po XVI w., wcześniej postać zawierała samogłoskę przednią wysoką pomiędzy nagłosowymi spółgłoskami. Pierwszy badacz nazwy, K. Zierhoffer (1957: 343), przytoczywszy zaledwie kilka z obfitej kolekcji dochowanych zapisów średniowiecznych, ${ }^{17}$ zrekonstruował postać piętnastowieczną jako

15 Nazwiska jego na stronie redakcyjnej matrycy nie podano. Redaktorami wydanych zeszytów z powiatami woj. warszawskiego byli nieznany mi bliżej prof. dr Leon Kaczmarek oraz prof. dr W. Doroszewski i dr Janina Wójtowicz.

16 Opracowanie Jaszkina (1971: 170) notuje brus. termin topograficzny rex 'pas pola ornego lub łąki kośnej', kontynuuje on jednak zapewne prapostać *grěxz w pierwotnym znaczeniu 'zagon pominięty przy orce lub siewie' (zob. o nim ÈSSJa VII 115-116; SP VIII 207-209, bez tych form brus.), por. praréx 'ahrech', uréx ‘ts.' (obok uhréx, Jaškin 1971: 193). Zanik h przed spółgłoską zachodzi na niewielką skalę w gwarach brus. Odesłanie tych wyrazów w ÈSBM IX 361 do hasła prarèx z leksemami o znaczeniu 'rozprucie odzieży; rozporek itp.' (strus. prorěxa) nie wydaje się uzasadnione.

17 Całość dokumentacji (według rękopiśmiennej kartoteki NMPol): de Szvmoszar [1397, kopia 1546] ZDM IV 298; de Schimoscharze [1417, kopia 1456] SHGMaz (MK 3, 117v-118); de Schimosarzs [1419, kopia 1456] ib. (ib. 3, 16); Schimoschars [1425] MKsM I nr 880; Simosarz [1428] ib. nr 581; de Schimoschari [1434] SHGMaz (MK 3, 134v); Schimoschars [1443, kopia 1456] ib. (ib. 3, 
Smosarz (!), bez próby interpretacji pozostawiając ją jako niejasną. Natomiast A. Bańkowski (1979: 489, przyp. 28), prawdopodobnie biorąc kadłubową dokumentację Zierhoffera za reprezentatywną, zinterpretował dwa zapisy z $\langle r s c h\rangle,\langle r s z>$ jako świadectwo występowania w nazwie grupy spółgłoskowej $r \dot{z}$, ściagniętej ostatecznie w $\check{r}>\check{z}$ (graficznie $r z$ ). Rekonstrukcja Szymoszarż została przezeń objaśniona jako struktura dzierżawcza pochodna od nie zaświadczonej i nieprzejrzystej etymologicznie nazwy osobowej („od niejasnej n. o. zakończonej na -ga”). Analiza całości dostępnych zapisów nie pozwala jednak na takie ujęcie. Przede wszystkim w najstarszym znanym zapisie, mogącym sięgać roku 1397, końcową spółgłoską jest zwykłe $-r(<-r>)$. Późniejsze zapisy mają zazwyczaj $\langle r z>$ lub $<-r s>$ (to ostatnie tylko W wygłosie), wskazujące dość wyraźnie na monofonematyczne $-\check{r}$. W dostępnych zapisach uderza ponadto częstość trigrafu $\langle s c h\rangle$, w piętnastowiecznych źródłach mazowieckich spotykanego w ogromnej większości przypadków przy brzmieniach z szumiącą $\check{s}$ (por. chociażby zapisy nazw z nagłosowym $S$ - i $S z$ - u Zierhoffera 1957 : 328-358). Nie znajdujemy wreszcie żadnych podstaw do rekonstrukcji dwu różnych spirantów (np. Szymos-). Uderza konsekwencja zapisywania tych głosek w taki sam sposób (zwykle $<s c h>$, sporadycznie $<s(z)>$ ); rozbieżność spotykamy tylko w dwu przypadkach, ale wymowa ich jest wzajemnie przeciwstawna $(<$ Schimosarz $>$, ale $<$ Szymoscharz $>$ ). Wynika stąd, że rekonstrukcja brzmienia Šymošar̆ (zapewne $\leftarrow$ Šimošar) jest stosunkowo pewnie ugruntowana (genezę obu $s$ tłumaczyć należy mazurzeniem, zanik $y$ jest nieoczekiwany ${ }^{18}$ ). Prób slawistycznej interpretacji takiego tworu należy poniechać, zważywszy na uderzający paralelizm budowy z również niejasną nazwą Parloszar. ${ }^{19}$

283v); Schimoscharze [1445, kopia 1456] ib. (ib. 3, 317v); de Schimoscharzs [1447, kopia 1456] ib. (ib. 4, 48); Schymorzas [1472] ib. (ib. 6, 19-19v); Schymoscharz [1483] ib. (ib. 6, 159); de Schymoscharz [1488] ib. (ib. 6, 214); de Symoszarz [1490, kopia]; de Szymoszars [1492, kopia] ib. (Ep 15, 140v); de Schimosarz [1493] ib. (MK 6, 273v); de Szymoscharz [1510, kopia] ib. (Ep. 119, 154); de Symosarz [1512, kopia] ib. (Ciech. gr. diss. 53, 25v); de Szymorzasch [1512, kopia] ib. (Ciech wiecz. 5, 41v); de Simosarz [1513, kopia] ib. (ib., 14); de Sumosarz, Simosarz [1520, kopia] ib. 204, 52; de Schymoscharsch [1522, kopia] ib. (ACPloc. 16); Szimosarsz [1567] ŹDz XVI 330; Smosarz Pianki [1783] MpPerMz; Smosarz pianki [1827] Tabella II 185; Smosarz Pianki [1890] SG X 918; Smosarz-Pianki, -rza-nek, cz. wsi [1971] UN CXXIII 14.

18 Przejściowo występowała także postać Szymorzasz (por. zapisy z lat 1472 i 1512). Genezę jej uzasadnia odkryta przez Bańkowskiego (1980: 6-7) tendencja do zwykle metatetycznego usuwania sekwencji -ž $V r^{\check{z}}$ - (i zapewne paralelnej $-\check{s} V r^{\grave{s}}$ ).

19 Tak standaryzuję postać nazwy ukrywającą się pod zapisem <cum additamento Parlosar dicte $>$ z roku 1524 SHGMaz (MK 32, 213) (por. Wolff, Rzetelska-Feleszko 1982: 128: nazwa niejasna, „może od nazwy osobowej, por. Parloszki SSNO”), lokalizowanej jednak na południowej peryferii Mazowsza (Bończa Nagórna w Wareckiem). Brak jotowania przemawia raczej przeciwko lekcji *Piarto-, która umożliwiałaby wiązanie nazwy z participium *pbrl- (od słowiańskich rodzin *pbrěti 'butwieć' lub *perti 'zamykać'). Prapostacią tej niejasnej nazwy wydaje się zatem *Płrlošarz lub *Parblošarz. 
Sona - nazwa rzeki, dużego (ponad $70 \mathrm{~km}$ ) dopływu dolnej Wkry, ${ }^{20}$ nad którym leży miejscowość Sońsk. Zaliczyłem ją do warstwy przejściowej I/II, rekonstruując z pewnym wahaniem postać *Suna jako wyjściową i przyjmując dla niej etymon w postaci przymiotnika *sun rekonstruowanego z apelatywu *sunica 'poziomka' (autor 2001: 336-337). Obecnie, po zapoznaniu się z usystematyzowanym materiałem i zwłaszcza z okolicznościami zewnętrznymi, nie widzę możliwości podtrzymania takiego stanowiska. Zapisy sugerujące $u$ występują tylko w dokumentacji nazwy Sońska, ${ }^{21}$ i nie zajmują wcześniejszej pozycji chronologicznej względem zapisów $\mathrm{z}<_{O}>$. Co więcej, całe dorzecze Sony leży w strefie, w której artykulacja $o$ podlega modyfikacji przez następujące spółgłoski nosowe; rezultatem jest bądź zwężenie/identyfikacja z ó pochylonym, bądź całkowite zrównanie z $u$ (zob. Dejna 1981: mapa 60). W XV-XVI w. mogło już dojść do zainicjowania tych procesów w postaci znaczniejszego zwężenia/podwyższenia samogłoski w tej pozycji, w zaawansowanym wieku XVI do pełnej identyfikacji $\mathrm{z} o$ pochylonym. Wprawdzie piętnastowieczna zmiana $\mathrm{w} u$ pozostaje nieoczekiwana, zwężenie byłoby jednak z pewnością czynnikiem, który zmianę taką ułatwiał. Skądinąd wiadomo, że zachodzace na skalę masową od XVI w. zwężanie samogłosek średnich w wysokie w toponimii polskiej wymyka się wszelkim regularnościom ustalanym dla zapisów leksyki apelatywnej. Natomiast odwrotna zmiana $u N>o N$, udokumentowana w niektórych nazwach mazowieckich (np. Stuńcewo > Stońcewo), dokonała się zapew-

20 Zapisy hydronimu: Sona [1425] MKsM I nr 106; Sona [1432] ib. nr 345; Sona [1440, kopia 1456] SHGMaz (MK 3, 153v); Zona [1502] ib. (Ep. 16, 149); Szona [1503] ib. (ib. 16, 185); (instr.) Ssona, Szonq [1565] LuMazXVI I 160, 166; Sona, (loc.) Sonie [1617] LuMazXVII I 32, 34; Sona [1775] ZZakr 88; Sona [1783] MpPerMz; Sonna Fl. [1808] MpTex XI; Rz. Sona [1839] MpKwat IV 2; Sona [1925] MTWIG-100(37-30); Sona al. Sonia [1890] SG XI 72; Sona a. Sonia (!) (=? Sowa) [1965] HW 212-213 (odc. 557).

Według Pacuskiego (2002: 182) należy tu także zapis $<$ Sonanys $>$, występujący we wtórnej kopii dyplomu z 1375 r. (NKDMaz III nr 163). Autor kierował się podobieństwem zapisu do nazwy płynącej niedaleko (górnej) Sony, nie rozpatrzył jednak kwestii od strony filologicznej. Według wydawców, dokument zachował się tylko w kopiach, dwie pierwsze (nry 1 i 2), sporządzone w latach 1563 i 1573, spłonęły w archiwum warszawskim w 1944 r., i nie są bezpośrednio dostępne współczesnym historykom. Zachowały się kopie nr 3 i 4, sporządzone wg kopii nr 1 (kopia nr 3 stała się podstawą wydania w NKDMaz III), oraz kopie nr 5 i 6, skopiowane z kopii nr 2. Zapis $<$ Sonanys $>$ występuje w kopii $\mathrm{nr} 6$, natomiast $\mathrm{w}$ innych występują postacie: $\mathrm{nr} 3-<$ Howanie $>$, nr $4-<$ Howaniec $>$, nr $5-<$ Honamys $>$. Uznanie $<S->$ za skrypcję właściwą oryginałowi wymagałoby zatem zakwestionowania literacji $\langle H-\rangle$ w co najmniej dwóch różnych tekstach, dokonywanych przez trzech różnych autorów. Dodajmy, że pisownia nazw i dość licznych wyrazów pospolitych (nazw powinności kmiecych) w kopiach dokumentu jest stosunkowo „przyzwoita”, co nie pozwala na łatwą interpretację formy < Sonanys $>$ w związku z postacią Sona.

21 Zapisy ojkonimu: Sansko [1385] KDKMaz 104; Sonsko [1424, kopia 1492] SHGMaz (MK 6, 290v); Sonsk [1426] MKsM I nr 304; Sonysko [1443, kopia 1456] SHGMaz (MK 3, 288v); in Sunska [1447, kopia 1456] ib. (ib. 4, 54v-55); Sonszko [1463] ib. (Ep. 9, 75v); Sonysko [1467] ib. (ib. 5, 86); Sonysk [1484] ib. (Ep. 11, 39v); Schonskowo, Schonsko [1498] ib. (MK 18, 132); Svnysko [1499, kopia 1506] ib. (ib. 18, 253v); Svnsko [1501] ib. (ib. 122); Sonsk, Sonsko [1516] ib. (Ep. 149, 241v); Szunsk [1567] ŹDz XVI 326; Sońsk [1827] Tabella II 188; Sońsk [1890] SG XI 74; Sońsk, -ka, soński [1971] UN CXXIII 35. Zapisy z 1498 r. sugerujące Sz- można uznać za hiperpoprawne wobec rozpowszechnionego już wówczas w tym rejonie mazurzenia. 
ne na innych terenach (głównie w Małopolsce, zob. Dejna 1981: mapa 44), i stamtąd przywędrowała na Mazowsze w konkretnych wyrazach.

Hydronim należy zatem rekonstruować jako Sona $<$ przedpolskie *Sona $<*$ San(przeciwko nagłosowemu $* \breve{S}_{-}$, nie wykluczanemu przez ograniczenia fonotaktyczne, przemawia brak większej liczby wczesnych zapisów z $<S c h->)$. W takiej postaci jest ona niejasna na gruncie słowiańskim, prawdopodobnie także całkowicie izolowana w toponimii północnosłowiańskiej. Brak także bezpośrednich nawiązań w hydronimii litewskiej (brak nazw na †San-, † zwą może być natomiast Sonarka (<Sonarka>), czternastowieczna (r. 1394) nazwa rzeki Gawarek koło Wyszogrodu (poza dorzeczem Narwi; SHGWysz 19, s.v. Gawarek), biegiem swym zbliżającej się do Sony na odległość ok. $20 \mathrm{~km}$.

$<$ Valanda $>$ - w takiej postaci ( $<$ fluvii Valanda $>$ ) w dyplomie z 1380 r. zapisano ówczesną nazwę odcinka rzeki noszącej dziś nazwę Różanica - prawego dopływu dolnej Narwi pod Różanem (por. NKDMaz III 287 [nr 270], z niezobowiązującą identyfikacją). W okolicy nie znaleziono żadnych innych śladów tej nazwy. Prawdopodobnie mamy tutaj strukturę porównywalną z omówioną wyżej Oględa, którą należałoby standaryzować jako Walęda $<*$ Valęda. ${ }^{22}$ Nieproduktywność takiego formantu w toponimii polskiej uniemożliwia dalszą analizę na gruncie rodzimym, mimo istnienia nawiązań apelatywnych (np. *valb, stpol. wat 'fala'). Morfem rdzenny $u \bar{a} l$ - > vāl-należy zresztą do mało charakterystycznych, powtarzając się w różnych językach (indo)europejskich, niekiedy w znaczeniach topo- czy hydrograficznych.

Porównanie ok. czterdziestu nazw wyznaczających uchwytny dzisiaj najstarszy horyzont nazewniczy słowiańskiej części dorzecza środkowej i dolnej Narwi pozwala na częściowe rozwinięcie generalizacji dokonanych przed kilkunastu laty. Od strony strukturalnej nazewnictwo to charakteryzuje się silną tendencją do przenoszenia do toponimii formacji złożonych (lub struktur slawizowanych jako formalne złożenia), o archaicznym typie indoeuropejskim (spójka $*_{-} a_{-}>_{--}-$). W zakresie fonetyki najbardziej chyba uderzającą cechą jest częstość wokalizmu $* a<* \bar{a}$ w transpozycjach słowiańskich, co podważa tezę o starogermańskich idiomach-dawcach tych nazw (jak wiadomo, w językach germańskich fazy z I połowy I tys. n.e. wokalizm $* \bar{a}$, pierwotnie zlikwidowany dzięki ogólnogermańskiej zmianie $* \bar{a}>* \bar{o}$ dokonanej w okolicy przełomu er, zaczynał się dopiero odradzać). Również nawiązania do realnie zaświadczonej leksyki toponimicznej historycznych języków bałtyckich są znikome. Rozsądne wydaje się dopatrywanie tu pozostałości bałtosłowiańskiego kontinuum językowego w postaci dialektów przejściowych między klasycznymi bałtyckim i słowiańskim obszarem językowym. Analiza wciąż skapego materiału nazewniczego nie pozwala jednak na oszacowanie skali nawiązań tego substratu do sąsiednich areałów prehistorycznych.

22 Sam zapis, analizowany bez kontekstu, dopuszcza lekcje Walęda $<*$ Valęda i Watęda $<*$ Valoda, a nawet $\mathrm{Wal}-\sim$ Wat- . 


\section{Źródła}

AtMaz - Atlas historyczny Polski. Mazowsze w drugiej połowie XVI wieku. II. Komentarz indeksowy. Red. W. Pałucki. Warszawa: Państwowe Wydawnictwo Naukowe, 1973.

HMil - Herbarz Ignacego Kapicy Milewskiego. Wyd. Z. Gloger. Kraków: W. Kirchmayer, 1870.

HO - Hydronimia Odry. Wykaz nazw w układzie hydrograficznym. Red. H. Borek. Opole: Instytut Śląski w Opolu, 1983.

HW - Hydronimia Wisty. I. Wykaz nazw w ukladzie hydrograficznym. Red. P. Zwoliński. Wrocław/Warszawa: Zakład Narodowy im. Ossolińskich, 1965.

KDKMaz - Kodeks dyplomatyczny księstwa Mazowieckiego. Wyd. J. T. Lubomirski. Warszawa: Drukarnia „Gazety Polskiej”, 1863.

LuMazXVI - Lustracja województwa mazowieckiego 1565. I-II i indeksy do cz. III (wyd. I. Gieysztorowa i A. Żaboklicka). Warszawa 1967-1971: Państwowe Wydawnictwo Naukowe.

LuMazXVII - Lustracje województwa mazowieckiego XVII wieku. I: 1617-1620. Wyd. A. Wawrzyńczyk. Wrocław/Warszawa/Kraków: Zakład Narodowy im. Ossolińskich, 1968.

MKsM - Metryka Księstwa Mazowieckiego z XV i XVI w. I. Księga oznaczona nr 333 z lat 1417-1429. II. Księga oznaczona nr 334 z lat 1429-1433. Wyd. A. Włodarski. Warszawa: Warszawskie Archiwum Główne, 1918-1930.

MpKwat-Topograficzna karta Królestwa Polskiego ... etc. Warszawa: Kwatermistrzostwo Generalne Wojska Polskiego, 1839.

MpPerMz - Mappa szczegulna woiewodztwa mazowieckiego zrzqdzona ... przez K. de Perthées. 1783.

MpTex - Topographisch-Militarische Karte von vormaligen Neu-Ostpreussen ... redigirt vom ... v. Textor. Wyd. D. F. Sotzmann). Berlin, 1808.

MTWIG - Mapy topograficzne. [Wojskowego Instytutu Geograficznego,] 1935. [Skala $1: 100000]$.

NKDMaz II - Nowy kodeks dyplomatyczny Mazowsza. II. Wyd. I. Sułkowska-Kuraś i S. Kuraś. Wrocław/Warszawa/Kraków/Gdańsk/Łodź: Zakład Narodowy im. Ossolińskich, 1989.

NKDMaz III - Nowy kodeks dyplomatyczny Mazowsza. III. Dokumenty z lat 13561381 (wyd. I. Sułkowska-Kuraś i S. Kuraś) Warszawa: DiG, 2000.

PRNG - Państwowy Rejestr Nazw Geograficznych. Pliki w formacie .xml dostępne pod adresem http://www.codgik.gov.pl/index.php/darmowe-dane/prng.html .

SG - Stownik geograficzny Królestwa Polskiego i innych krajów stowiańskich. IXV. Warszawa: Nakładem Filipa Sulimierskiego i Władysława Walewskiego, 1880-1902.

SHGMaz - kartoteka Stownika historyczno-geograficznego Mazowsza (symbole poszczególnych źródeł niepublikowanych: AG - dokumenty pergaminowe z Archiwum Głównego Akt Dawnych; Ep. - Episcopalia, księgi sądów biskupich; MK - księgi Metryki Ksiażęcej; Roż. - różańskie księgi wieczyste; Ciech. wiecz. 
- ciechanowskie księgi wieczyste; Ciech. gr. diss. - ciechanowska księga grodzka (dissoluta). Rękopisy w archiwach Warszawy i Płocka, cytowane za NMPol i jego kartoteką oraz Wolffem i Rzetelską-Feleszko, 1982.

SHGWysz - Adam Wolff, Anna Borkiewicz-Celińska, Słownik historyczno-geograficzny ziemi wyszogrodzkiej w średniowieczu. Wrocław/Warszawa/Kraków: Zakład Narodowy im. Ossolińskich, 1971.

Snazw - Stownik nazwisk współcześnie w Polsce używanych. I-X. Wyd. K. Rymut. Kraków: Instytut Języka Polskiego PAN, 1992-1994.

SSNO - Stownik staropolskich nazw osobowych. I-VII (Suplement). Wrocław etc.: Zakład Narodowy im. Ossolińskich, 1965-1987.

Tabella - Tabella miast, wsi, osad Królestwa polskiego z wyrażeniem ich położenia $i$ ludności. I-II. Warszawa: Drukarnia Łątkiewicza, 1827.

UN - Urzędowe nazwy miejscowości i obiektów fizjograficznych. I-. Warszawa 1963-: Urząd Rady Ministrów. Wykorzystano zeszyty z pow. chrzanowskiego, mławskiego i przasnyskiego oraz niepublikowane matryce zeszytów ostrołęckiego, pułtuskiego i łomżyńskiego.

UNMasz - niepublikowane tzw. „maszynopisy profesorskie” z nazwami miejscowości i obiektów fizjograficznych. Wykorzystano maszynopisy powiatów ostrołęckiego, mławskiego, pułtuskiego, zambrowskiego i łomżyńskiego. [Maszynopisy/matryce obecnie w archiwum IJP PAN w Krakowie, kopie cyfrowe pod adresem: http://rcin. org.pl/dlibra/docmetadata?id=53508].

ZDM IV - Zbiór dokumentów małopolskich. IV. Dokumenty z lat 1211-1400. Wyd. S. Kuraś i I. Sułkowska-Kuraś. Wrocław/Warszawa/Kraków: Zakład Narodowy im. Ossolińskich, 1969.

ZMak - Materiały do dziejów ziemi płockiej. 6: Ziemia makowska. Opr. M. M. Grzybowski. Płock: Towarzystwo Naukowe Płockie, 1991.

ZZakr - Materiały do dziejów ziemi płockiej. 5: Ziemia zakroczymska. Opr. M. M. Grzybowski. Płock: Towarzystwo Naukowe Płockie, 1998.

ŹDz XVI - Polska XVI wieku pod względem geograficzno-statystycznym. V. Mazowsze. Wyd. A. Pawiński. Warszawa: Księgarnia Gebethnera i Wolffa, 1895.

\section{Literatura cytowana}

BABIK, Zbigniew (2001) Najstarsza warstwa nazewnicza na ziemiach polskich (w granicach wczesnośredniowiecznej Stowiańszczyzny). Kraków: Universitas.

BABIK, Zbigniew (2004) „Mława.” Onomastica 48, 139-150.

BABIK, Zbigniew (2008) „Historische Quellenforschung und philologisch-linguistische Analyse bei toponomastischen Untersuchungen (eine Polemik mit E. Kowalczyk)." Studia Etymologica Cracoviensia 13, 23-46.

BAŃKOWSKI, Andrzej (1979) „Szkice z polskiej etymologii onomastycznej II.” Poradnik Językowy, 483-494.

BAŃKOWSKI, Andrzej (1980) „Metateza w toponimii polskiej.” Rozprawy Komisji Językowej Łódzkiego Towarzystwa Naukowego 25, 5-15. 
BAŃKOWSKI, Andrzej (1982) Zmiany morfemiczne w toponimii polskiej. Wrocław/ Warszawa/Kraków/Gdańsk: Zakład Narodowy im. Ossolińskich.

BASARA, Anna (1984) Opisy fonologiczne polskich punktów Ogólnosłowiańskiego atlasu językowego. III. Mazowsze. Wrocław/Warszawa/Kraków/Gdańsk/Łódź: Zakład Narodowy im. Ossolińskich.

DEJNA, Karol (1981) Atlas polskich innowacji dialektalnych. Warszawa/Łódź: Państwowe Wydawnictwo Naukowe.

DOMAŃSKI, Józef (1989) „Budowa słowotwórcza dawnych słowiańskich nazw rzecznych na Śląsku.” W: K. Rymut (red.), 167-175.

ÈSBM - Ėtymalahičny sloŭnik belaruskaj movy. I-. Red. V. U. Martynaŭ i inni. Minsk: Vydavectva „Navuka i tèchnika”, 1978-.

ÈSSJa - Ėtimologičeskij slovar' slavjanskich jazykov. Praslavjanskij leksičeskij fond. I-. Red. O. N. Trubačev. Moskva: Izdatel'stvo Nauka, 1974-.

JAŠKIN, Ivan Ja. (1971) Belaruskija heahrafičnyja nazvy. Tapahrafija. Hidralohija. Minsk: Vydavectva „Navuka i tèchnika”.

LEHMANN, Winfried P. (1986) A Gothic etymological dictionary (based on the third edition of Vergleichendes Wörterbuch der gotischen Sprache by Sigmund Feist). Leiden: Brill.

MAŽIULIS, Vytautas (1988-1997) Prūsu kalbos etimologijos žodynas. I-IV. Vilnius: Mokslas.

NMPol-Nazwy miejscowe Polski. Pochodzenie-Historia-Zmiany. I-(red. K. Rymut, potem B. Czopek-Kopciuch). Kraków: Instytut Języka Polskiego PAN, 1996-.

PACUSKI, Kazimierz (2002) „Uzupełnienia i sprostowania do Nowego kodeksu dyplomatycznego Mazowsza, część III: dokumenty z lat 1356-1381." Studia Źródtoznawcze 40, 167-200.

PRZYBYTEK, Rozalia (1993) Ortsnamen baltischer Herkunft im südlichen Teil Ostpreussens. Stuttgart: Franz Steiner Verlag.

RYMUT, Kazimierz (red.) (1989) Hydronimia stowiańska. Materiaty z IX konferencji Komisji Onomastyki Słowiańskiej przy Międzynarodowym Komitecie Slawistów (Mogilany, 16-18 IX 1986 r.). Wrocław/Warszawa/Kraków/Gdańsk/Łódź: Zakład Narodowy im. Ossolińskich.

SNGŚ II - Stownik nazw geograficznych Ślaska II. C-D. Red. S. Rospond i H. Borek. Warszawa/Wrocław etc.: Państwowe Wydawnictwo Naukowe, 1980.

SP - Stownik prastowiański. I-. Red. F. Sławski. Wrocław/Warszawa/Kraków: Zakład Narodowy im. Ossolińskich, 1974-.

TOPOROV, Vladimir N. (1975-1990) Prusskijjazyk. Slovar'. I-V. Moskva: Izdatel'stvo Nauka.

VANAGAS, Aleksandras (1970) Lietuvos TSR hidronimu daryba. Vilnius: Mintis. WOLFF, Adam/Ewa RZETELSKA-FELESZKO (1982) Mazowieckie nazwy terenowe do końca XVI w. Warszawa: Państwowe Wydawnictwo Naukowe.

ZIERHOFFER, Karol (1957) Nazwy miejscowe pótnocnego Mazowsza. Wrocław: Zakład im. Ossolińskich. 


\section{Streszczenie \\ PRZEDSŁOWIAŃSKA WARSTWA NAZEWNICZA PÓŁNOCNEGO MAZOWSZA - POPRAWKI I UZUPEŁNIENIA (DORZECZE NARWI)}

Artykuł stanowi uzupełnienie dokonanego przez autora opracowania najstarszej/ przedhistorycznej warstwy nazewniczej ziem polskich z 2001. Północne Mazowsze, będące wyłącznym przedmiotem niniejszego opracowania, podlegało slawizacji zapewne później niż obszary położone między Wisłą i Odrą. Wskazuje na to m.in. stosunkowo gęsty substrat przedsłowiański, widoczny zwłaszcza w hydronimii dorzecza Narwi (co najmniej 40 przykładów, w tym 15 nowych). Nazwy te rzucają się w oczy swą nieprzejrzystością etymologiczną i nazwotwórczą na gruncie słowiańskim i polskim, zwłaszcza w wypadku nazw o strukturze złożeń. Szczególną uwagę poświęcono rekonstrukcji późnoprasłowiańskich postaci tych nazw, w zasadzie pominięto natomiast aspekt ściśle etymologiczny. Odpowiednie praformy zrekonstruowano jako *XaxъluZa (?), *Dusveta, *(J)aboraZ-, *Kupesb (masc.), *Lutostanb -i, *Manskanb (3x), *Nuna $\sim{ }^{*}$ Nona, *Og(z)lęda, *Rudoky - bve, *Siryga, *Sona, *Šimošarb, *RExostanb -i *ŽExostanb $-i$, *Ružb (2x), *Valęda. Wyodrębnione nazwy substratowe pochodzą zapewne z nieznanych języków indoeuropejskich używanych na tym obszarze u schyłku starożytności, może stanowiących areał przejściowy między słowiańskim a bałtyckim. Można wykazać, że w wielu wypadkach pośrednictwo starogermańskie musi zostać wykluczone (wokalizm $* a<* \bar{a}$ ).

Słowa kluczowe: najstarsza toponimia mazowiecka, dorzecze Narwi, substrat przedsłowiański

\section{Abstract \\ PRE-SLAVIC TOPONOMASTIC LAYER OF NORTHERN MAZOVIA: CORRECTIONS AND ADDENDA (THE NAREW DRAINAGE)}

The paper offers a supplement to the author's treatment of the oldest/prehistoric layer of Polish toponymy as exemplified in his 2001 book. Northern Mazovia, to which the present investigation is restricted, was probably Slavicized at a later date than the area situated between the Vistula and the Oder. This is evidenced inter alia by a relatively dense Pre-Slavic toponymic substratum, visible above all in the hydronymy of the Narew drainage basin (at least 40 instances, including 16 new). These names appear unclear and peculiar from the Slavic point of view (a salient lack of lexical and/or morphological motivation in the reconstructed Slavic and historical Polish, particularly striking in case of compounds). Attention is focused mainly on the reconstruction of the Late Common Slavic forms of these names, while their etymology is as a rule not discussed. Their proto-forms have been reconstructed as *XaxъluZa (?), *Dusveta, *(J)aboraZ-, *Kuposb (masc.), *Lutostanb -i, *Manbkanb (3x), *Nuna *Nona, *Og(z) lęda, *Rudoky -ъve, *Siryga, *Sona, *Šimošarb, *RExostan $-i \sim *$ ŽExostan $-i, * R u \check{b} b(2 \mathrm{x}),{ }^{*}$ Valęda. These substratum names come probably from Indo-European 
languages used in that area in Late Antiquity, possibly forming a transition area between Baltic and Slavic. It can be shown that in many cases (vocalism $* a<* \bar{a}$ ) an Old Germanic intermediary must be ruled out.

Keywords: oldest Mazovian toponymy, the Narew drainage, Pre-Slavic substratum

\section{Povzetek \\ PREDSLOVANSKA IMENSKA PLAST SEVERNE MAZOVIJE - POPRAVKI IN DOPOLNITVE (POREČJE NARVE)}

Članek predstavlja dopolnitev avtorjeve obravnave najstarejše/predzgodovinske imenske plasti na poljskem ozemlju iz leta 2001. Severna Mazovija, ki je izključni predmet pričujoče obravnave, je bila zelo verjetno slavizirana pozneje kot območje med Vislo in Odro. Na to kaže med drugim razmeroma gost predslovanski substrat, opazen zlasti v hidronimiji porečja Narve (najmanj 40 primerov, od tega 15 novih). Ta imena izstopajo s svojo etimološko in imenotvorno neprozornostjo, če jih skušamo razložiti na slovanski in poljski podlagi, zlasti še v primeru imen, ki so po svoji strukturi zloženke. Posebna pozornost je posvečena rekonstrukciji poznopraslovanskih oblik teh imen, zato pa je načeloma opuščen čisto etimološki vidik. Ustrezne prvotne oblike se rekonstruirajo kot *XaxbluZa (?), *Dusveta, *(J)aboraZ-, *Kuposb (masc.), *Lutostanb -i, *Manbkanь (3x), *Nuna *Nona, *Og(b)lęda, *Rudoky -ъve, *Siryga, *Sona, *Šimošarb, *Rexostan $-i \sim *$ Žexostan $-i,{ }^{*}$ Ružb $(2 \mathrm{x}),{ }^{*}$ Valęda. Navedena substratna imena zelo verjetno izvirajo iz neznanih indoevropskih jezikov, ki so jih govorili na tem prostoru ob zatonu antike in so morda predstavljali prehodno območje med slovanskim in baltskim jezikovnim arealom. Da se dokazati, da je v številnih primerih starogermansko posredništvo izključeno (vokalizem $* a<* \bar{a}$ ).

Ključne besede: najstarejša mazovska toponimija, porečje Narve, predslovanski substrat 